\title{
STUDI PERILAKU CHEATING SISWA MADRASAH DAN SEKOLAH ISLAM KETIKA UJIAN NASIONAL
}

\author{
Kusaeri \\ UIN Sunan Ampel Surabaya, Jawa Timur, Indonesia \\ kusaeri@uinsby.ac.id
}

\begin{abstract}
Abstrak
Penelitian ini bertujuan mengungkap cheating di MA/SMA Islam di Jawa Timur berdasarkan capaian UN dan IIUN 2015. Dengan pendekatan deskriptif, data penelitian disajikan secara naratif, dilengkapi dengan persentase, tabel, grafik dan bagan. Data diperoleh dari Pusat Penilaian Pendidikan Balitbang Kemendikbud. Seluruh MA/SMA Islam di Jawa Timur sebanyak 1.117 dijadikan sampel karena jumlahnya terbanyak (dari 6.608 MA/SMA Islam di Indonesia). Data dianalisis dengan pengodean, pencatatan, penabelan, serta perhitungan statistik. Indeks cheating ditentukan menggunakan metode Pair Wise dan Metode Kumulatif. Hasil penelitian menunjukkan bahwa 5,26\% siswa MA/SMA Islam di Jawa Timur memenuhi kriteria kelulusan UN (nilai di atas 55) dengan IIUN lebih dari 70. Sebaliknya, 40\% dari siswa SMA Kristen/ Katolik memperoleh nilai UN di atas 55 dengan IIUN lebih dari 70. Hasil ini menggambarkan perilaku cheating di kalangan siswa MA/ SMA Islam di Jawa Timur lebih tinggi dibandingkan siswa SMA Kristen/ Katolik.
\end{abstract}

Kata Kunci: menyontek; madrasah; ujian nasional; IIUN. 


\begin{abstract}
THE STUDY OF MADRASA AND ISLAMIC SCHOOL STUDENTS' CHEATING BEHAVIOR IN NATIONAL EXAMINATION. This study describes the cheating in Madrasah/Islamic High Schools in East Java. It is based on the achievement of UN and IIUN 2015. It used descriptive approach. The data were presented in narrative, percentage, tables, graphs, and charts. Data were obtained from Center of Education Assessment, Balitbang Kemendikbud. East Java was chosen because it is province with highest number $(1,117)$ from 6.608 Madrasah/Islamic High Schools in Indonesia. The data were analysed using encoding, recording, diagraming, and statistical calculations. Cheating index was determined using the Pair Wise and Cumulative Method. The results showed that 5.26\% of Madrasah/Islamic High School students reached the graduation criteria (UN score above 55) with IIUN more than 70. Contrastly, 40\% of Christian/Catholic High Schools students obtained UN score above 55 with IIUN more than 70 . These results illustrated the cheating among Madrasah/Islamic High School students in East Java was higher than Christian/Catholic High School students.
\end{abstract}

Keywords: cheating; madrasah; national exam; IIUN.

\title{
A. Pendahuluan
}

Secara kelembagaan, eksistensi madrasah sebagai lembaga pendidikan dalam konteks sistem pendidikan nasional telah mendapat status seperti halnya sekolah (Supa'at, 2013:336). Secara yuridis, pengakuan tersebut tertuang dalam Undang-undang Nomor 20 tahun 2003 tentang Sistem Pendidikan Nasional, yakni madrasah merupakan bagian yang tak terpisahkan dari sistem pendidikan formal di Indonesia. Pengakuan ini menjadi penting bagi madrasah, karena telah lama madrasah kurang mendapatkan perhatian yang sewajarnya dari pemerintah. Hal itu terjadi karena madrasah lebih dipandang sebagai lembaga dakwah (lembaga keagamaan) daripada sebagai lembaga pendidikan.

Jumlah madrasah di Indonesia saat ini tercatat ada 76.551 madrasah (Kemenag, 2015:2). Jumlah tersebut terus bertambah seiring dengan kian bertambahnya kepercayaan masyarakat terhadap madrasah akhir-akhir ini. Bertambahnya minat masyarakat terhadap madrasah merupakan bukti nyata atas meningkatnya kualitas dan mutu madrasah. Meskipun begitu, 
masyarakat perlu tahu secara utuh tentang madrasah di Indonesia sebagai modal pengetahuan mereka dalam menilai, memilih, dan mengontrol kualitas madrasah.

Salah satunya pengetahuan tentang prestasi siswa madrasah dalam ujian nasional (UN). Termasuk kelemahan yang mungkin terjadi di madrasah ketika pelaksanaan UN. Misalnya, kelemahan berupa tindak penyimpangan yang dilakukan oleh sebagian siswa madrasah. Sebab, keikutsertaan madrasah dalam UN merupakan konsekuensi logis menyatunya sistem pendidikan madrasah dalam sistem pendidikan nasional. Apapun yang terjadi dan apapun hasilnya, semua madarasah harus tunduk dan mengikuti kebijakan tersebut.

Bila menengok visi Kemenag, madrasah tidak hanya mencetak siswa intelektual yang pintar, melainkan juga siswa muslim yang berintegritas, berkarakter, dan berakhlaq mulia. Tentu saja, visi tersebut tidak ingin dinodai oleh perilaku-perilaku tidak terpuji seperti menyontek. Nilai-nilai luhur yang diajarkan di madrasah seperti aqidah, akhlaq, fiqih, al-qur'an, dan hadits diharapkan dapat menjadi benteng yang dapat menjauhkan dari sikap-sikap tidak terpuji dan dapat membangun keimanan siswa.

Bagaimana keimanan bisa mempengaruhi sikap siswa dari menyontek? Iman merupakan salah satu dimensi yang paling esensial dalam beragama. Iman merupakan dasar pemikiran bagi kehidupan praktis manusia (Maududi, 1986: 3). Tingkat keimanan seorang siswa akan berpengaruh pada berbagai aspek kehidupan, termasuk kaitannya dengan perilaku menyontek. Iman yang mantap dalam jiwa seorang siswa akan mengangkat mereka ke tingkat moral yang luhur, sehingga menjauhkan mereka dari sifat-sifat tidak terpuji (Sabiq, tt: 25), seperti berbuat curang atau menyontek. Mereka meyakini bahwa ajaran Islam merupakan ajaran yang kebenarannya tidak diragukan lagi. Hal ini akan mempengaruhi komponen keyakinan sikapnya terhadap menyontek, yang selanjutnya mempengaruhi perilakunya.

Mencontek dalam bahasa Arab disebut ghish (الغش) dan khadiah (الخديعة) yang berarti tipu daya. Dalam bahasa Inggris, kata menyontek sama artinya dengan cheating. Secara istilah menyontek merupakan bentuk upaya agar dapat mencapai 
keberhasilan melalui cara-cara yang curang (Warsiyah, 2013: 3). Sebagai suatu bentuk perilaku, cheating dapat diamati dan tidak terlepas dari beberapa dugaan penyebab seperti adanya pengaruh lingkungan atau pengalaman yang terbentuk akibat interaksi yang dilakukan dengan lingkungannya.

Penyebab perilaku cheating dapat didekati dari teori "Fraud Triangle." Dijelaskan bahwa ada tiga hal yang menjadi penyebab siswa melakukan cheating (Albrecht, 2012), yakni: tekanan (pressure), kesempatan (opportunity) dan rasionalisasi (rationalize). Tekanan merupakan suatu situasi dimana seorang siswa merasa perlu untuk melakukan cheating. Semakin tinggi tekanan, semakin besar kemungkinan perilaku cheating terjadi. Tekanan yang dimaksudkan adalah tekanan yang dialami oleh siswa sebagai faktor pendorong mereka melakukan cheating. Jadi tekanan dalam konteks cheating merupakan dorongan maupun motivasi yang dihadapi siswa dalam kesehariannya yang mempunyai hubungan dengan masalah akademik dan menyebabkan mereka memiliki tekanan yang kuat untuk mendapatkan hasil akademik yang terbaik dengan cara apapun. Pandangan masyarakat yang mendewakan prestasi diukur dari nilai yang tinggi, membuat siswa terpaku untuk memperoleh nilai tinggi dengan cara apa pun. Tekanan memiliki pengaruh yang signifikan terhadap perilaku cheating yang dilakukan siswa (Becker, dkk, 2006: 37-53). Becker juga mengemukakan adanya kemungkinan terjadinya cheating secara skala besar, ketika tekanan yang dihadapi siswa semakin besar.

Selanjutnya, kesempatan merupakan suatu situasi dimana seorang siswa merasa memiliki kombinasi situasi dan kondisi yang memungkinkan melakukan cheating dan tidak terdeteksi. Tentunya hal ini menjadikan sebuah kemudahan bagi pelaku cheating. Semakin meningkatnya kesempatan yang didapat, semakin besar kemungkinan perilaku cheating. Kesempatan akan hadir ketika adanya sebuah kelemahan di dalam suatu sistem yang ada. Minimnya kontrol serta kurang ditegakkannya sanksi merupakan hal utama pendorong munculnya kesempatan (Albrecht, 2012) Dengan demikian, kesempatan merupakan faktor yang paling 
mudah untuk diminimalisasi dan diantisipasi, ketika sudah tercipta sistem yang baik dan pengendaliannya bagus.

Rasionalisasi adalah pembenaran diri sendiri atau alasan yang salah untuk suatu perilaku yang salah. Rasionalisasi dapat diartikan sebagai suatu sikap atau anggapan pribadi bahwa kecurangan merupakan tindakan yang tidak salah. Dalam Kamus Besar Bahasa Indonesia (KBBI), rasionalisasi didefinisikan sebagai proses atau cara untuk menjadikan sesuatu yang tidak rasional menjadi rasional (dapat diterima akal sehat) atau menjadi sesuatu yang baik (Depdikbud, 2008). Berdasarkan pengertian ini, rasionalisasi dalam tindakan cheating merupakan sebuah perilaku pembenaran diri yang dilakukan untuk mengurangi rasa bersalah yang timbul karena telah melakukan perbuatan yang tidak jujur dalam konteks akademik. Rasionalisasi menyangkut perasaan setiap individu. Faktor ini sedikit lebih sulit dibandingkan dengan dua faktor sebelumnya. Berbagai penelitian tentang cheating yang telah dilakukan, baik di luar maupun di dalam negeri, mengindikasikan bahwa perilaku ini sudah menjadi budaya dan sekaligus "wabah" yang telah menyerang sebagian besar siswa di dunia. Wabah cheating diduga telah ada sejak tiga abad yang lalu ditemukan di berbagai belahan dunia.

Studi awal yang berhasil ditemukan dilakukan di Amerika Serikat pada siswa SMP untuk melihat banyaknya siswa yang melakukan cheating dalam ujian dan banyaknya siswa yang jujur selama ujian (Stainer, 1932: 535 - 546 ). Hasilnya, jumlah siswa yang cheating dalam pelaksanaan ujian sangat banyak dibandingkan yang tidak. Penelitian selanjutnya dilakukan terhadap 126 orang siswa (Drake, 1941), dan ditemukan terdapat $23 \%$ dari mereka mengaku melakukan cheating. Mereka yang melakukan cheating cenderung siswa yang kurang cerdas. Hasil penelitian ini menunjukkan bahwa aspek kejujuran menjadi hal yang sangat penting dalam pelaksanaan suatu tes. Kecenderungan bahwa siswa yang melakukan cheating adalah siswa yang memiliki kemampuan rendah dengan berbagai pola dan bentuk sesuai dengan strategi yang mereka sepakati.

Bentuk-bentuk cheating yang sering terjadi, di antaranya membuka buku saat ujian, menyalin pekerjaan siswa lain, serta 
siswa dengan sengaja membiarkan siswa lain menyalin pekerjaan yang dimilikinya (Bushway dan Nash, 1977). Alasan mereka melakukan hal itu untuk mendapatkan nilai yang baik. Selain itu, tekanan dari guru dan orang tua juga ikut berpengaruh, serta siswa takut gagal. Juga ditemukan bahwa sekitar $40 \%$ siswa kelas 6 (enam) melakukan praktik menyalin (copying) dan sekitar 60\% mahasiswa di beberapa tempat melakukan praktik kecurangan selama menjadi mahasiswa (Cizek, 1999).

Perilaku cheating juga ditemukan pada siswa di Australia, Inggris, India, Jepang, Korea, Spanyol, dan Skotlandia (Strom \& Storm, 2007: 104-116). Di China, akhirnya diterapkan sanksi bagi mahasiswa yang cheating diganjar hukuman 7 tahun penjara (Hartanto, 2012). Kasus cheating di kalangan mahasiswa di Indonesia juga pernah diungkap. Sekitar $80 \%$ mahasiswa Fakultas Ekonomi (FE) Universitas Negeri Padang (UNP), melakukan cheating saat ujian berlangsung (Friyatmi, 2011: 173-188).

Penelitian lain dilakukan untuk menguji pengaruh tingkat keimanan dan prokrastinasi akademik terhadap perilaku cheating (Warsiyah, 2013). Penelitian ini melibatkan 197 orang mahasiswa Fakultas Tarbiyah IAIN Walisongo Semarang. Didapati kesimpulan, tingkat keimanan secara empiris memiliki pengaruh langsung yang negatif terhadap perilaku cheating. Sementara itu, prokrastinasi akademik secara empiris memiliki pengaruh langsung positif terhadap perilaku cheating. Manopo dan Mardapi (2014: 115-128) melakukan penelitian guna mendeteksi perilaku cheating pada siswa SMA/MA Negeri di Provinsi Maluku tahun pelajaran 2011/2012. Hasilnya cukup mengejutkan. Dari 1.620 siswa yang dijadikan sampel, sebanyak 1.556 siswa melakukan cheating. Bila dibuat prosentase, maka siswa yang melakukan cheating sebanyak 96,04\%. Suatu jumlah yang tidak sedikit.

Dari serangkaian penelitian yang telah dilakukan sebelumnya, terlihat tak satupun yang berupaya mengungkap perilaku cheating di kalangan siswa madrasah dan sekolah Islam. Pengungkapan perilaku cheating dalam konteks ini tidak dimaksudkan untuk membuka "aib" madrasah dan sekolah Islam. Akan tetapi, dalam rangka evaluasi diri dan berbenah agar generasi Islam ke depan tidak terjebak dalam perilaku tercela yang 
mengingkari roh dan semangat Islam. Hal ini diterangkan dalam firman Allah dalam surat Al-Baqarah ayat 9: "Mereka hendak menipu Allah dan orang-orang yang beriman. Padahal mereka hanya menipu dirinya sendiri sedang mereka tidak sadar."

Sebab dampak cheating bila dibiarkan, akan terasa dalam jangka pendek maupun panjang. Jangka pendek, siswa madrasah dan sekolah Islam menjadi tidak percaya diri. Melakukan apapun selalu bergantung orang lain. Tidak yakin dengan kemampuan yang dimilikinya. Dalam jangka panjang, bagi mereka yang terbiasa melakukan cheating, kebiasaan itu akan membentuk dan melekat pada diri mereka. Saat mereka sudah dewasa, tabiat-tabiat dampak perilaku cheating mulai diterapkan dalam kehidupan seharihari, seperti korupsi, mencuri, serta pemalas tetapi ingin jabatan dan pendapatan tinggi. Siswa yang menganggap wajar perilaku cheating, mereka akan cenderung untuk sering melakukannya. Nantinya mereka akan melakukan hal yang sama di tempat kerja (Nonis \& Swift, 2001: 69-77). Karena itu, perilaku cheating harus dihindari dan tidak selayaknya dilakukan oleh siswa madrasah dan sekolah-sekolah Islam.

Itulah sebabnya, madrasah dan sekolah-sekolah Islam harus memberikan perhatian lebih terhadap perilaku ini. Membuang jauh dan menutup rapat kesempatan siswa melakukan cheating. Pembenahan sistem dan pemberian sanksi yang tegas bagi siswa yang melakukan cheating merupakan hal yang mutlak dan perlu dilakukan. Sejak tahun 2015, Kemendikbud menerbitkan kebijakan berupa dihapuskanya Ujian Nasional (UN) sebagai penentu kelulusan dan terbitnya Indeks Integritas Ujian Nasional (IIUN). Kebijakan ini lahir sebagai upaya menekan perilaku cheating di kalangan siswa.

Data capaian UN dan IIUN yang dikeluarkan Kemendikbud, dapat dimanfaatkan oleh madrasah dan sekolahsekolah Islam untuk berbenah dan memerangi perilaku tercela, cheating. Capaian UN dan tingkat kejujuran (IIUN) menunjukkan kredibiltas suatu madrasah atau sekolah Islam ketika melaksanakan UN. Dalam laporan Kemendikbud (2015) disebutkan bahwa sebagian madrasah dan sekolah-sekolah Islam memperoleh capaian UN tinggi dan IIUN yang tinggi. Sebagian 
yang lain memperoleh capaian UN rendah dan IIUN rendah pula. Namun, sebagian madrasah dan sekolah-sekolah Islam memperoleh capaian UN tinggi tetapi IIUN sangat rendah. Yang paling tragis, sebagian madrasah dan sekolah Islam memperoleh capaian UN rendah dan IIUN yang rendah pula. Kondisi tersebut diilustrasikan sebagaimana Gambar 1. Dengan demikian, dapat diidentifikasi mana madrasah dan sekolah-sekolah Islam yang kredibel atau berkualitas dan mana yang tidak.

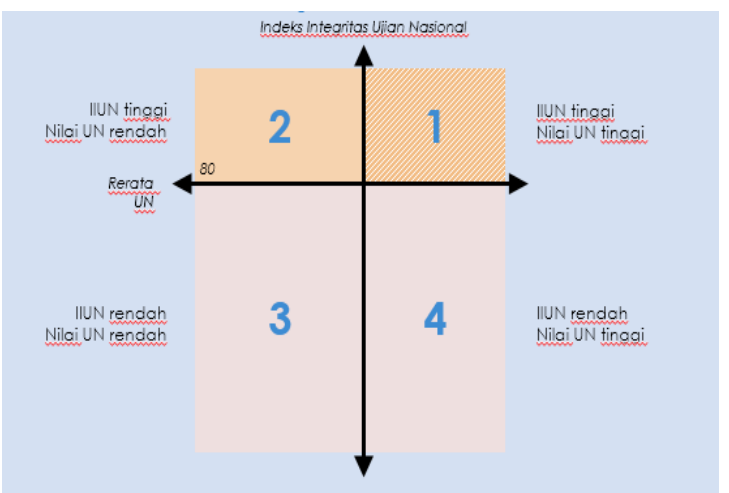

Gambar 1. Ilustrasi Matriks Capaian UN dan IIUN

Sederat fenomena yang disajikan di atas menggambarkan bahwa cheating merupakan suatu permasalahan yang menarik untuk dianalisis lebih lanjut. Terlebih bila objeknya madrasah dan sekolah-sekolah Islam. Oleh karena itu, tulisan ini akan fokus mengungkap perilaku cheating yang terjadi di madrasah dan sekolah-sekolah Islam di Jawa Timur. Pengungkapan didasarkan pada capaian UN dan IIUN masing-masing madrasah dan sekolah Islam. Sebagai bahan refleksi, hasilnya akan disandingkan dengan perilaku cheating yang terjadi di sekolah-sekolah non-Islam. Berdasarkan uraian tersebut, maka rumusan masalah dalam penelitian ini adalah: "Bagaimanakah perilaku cheating siswa MA dan SMA Islam di Jawa Timur, berdasarkan nilai UN dan IIUN tahun 2015?"

Dalam pelaksanaanya, penelitian ini dirancang menggunakan pendekatan deskriptif. Pendekatan ini memungkinkan data disajikan secara naratif, dilengkapi dengan persentase, dipertegas dengan sajian tabel, dan grafik. Dengan 
demikian, sajian data menjadi lebih kaya, mudah dibaca dan menarik untuk disimak.

Pengungkapan perilaku cheating didasarkan pada data capaian UN dan IIUN siswa madrasah serta sekolah Islam tahun 2015. Data diambil dari laporan UN tahun 2015 yang dibuat oleh Pusat Penilaian Pendidikan (Puspendik) Balitbang Kemendikbud. Demikian pula data Indeks Integritas Ujian Nasional (IIUN). IIUN merupakan persentase jawaban siswa yang tidak menunjukkan pola kecurangan. Kecurangan yang diukur adalah gabungan persentase contek mencontek antar siswa (kecurangan antar individu) dan persentase keseragaman pola jawaban (kecurangan sistemik/terorganisir) dalam suatu sekolah.

IIUN dilaporkan dalam rentang indeks 0 sampai dengan 100. Indeks 0 menunjukkan integritas pelaksanaan UN yang paling rendah. Terjadi kecurangan atau cheating masal di madrasah atau sekolah tersebut. Seluruh jawaban siswa di sekolah atau madrasah itu semuanya sama polanya. Indeks 100 menunjukkan integritas pelaksanaan UN yang paling tinggi. Tak satupun saling contek antar siswa yang terjadi di madrasah dan sekolah itu. Ditandai dengan pola jawaban yang alami, dan berbeda antar satu siswa dengan siswa lainya.

Indeks cheating dibuat berdasarkan pola jawaban siswa ketika mengerjakan UN. Metode penentuan indeks cheating yang digunakan oleh Kemendikbud (2015) dilakukan melalui 2 tahapan, yaitu Metode Pair Wise, dan Metode Kumulatif. Dari metode pair wise didapatkan potret keseragaman jawaban dua siswa pada suatu madrasah. Misalkan, siswa $\mathrm{C}$ dengan indeks pair wise 70 pada mata pelajaran Bahasa Indonesia. Hal itu menunjukkan pola jawaban yang dimilikinya pada ujian Bahasa Indonesia $70 \%$ sama dengan siswa lain. Dari keseluruhan indeks pair wise dalam satu madrasah, diperoleh indeks kumulatif. Indeks ini menunjukkan nilai rata-rata indeks pair wise setiap siswa di madrasah tersebut. Indeks kumulatif tingkat madrasah menggambarkan keseragaman pola jawaban pada minimal $80 \%$ peserta ujian di suatu madrasah. Indeks ini dilaporkan dalam rentang 0-100, dikelompokkan dalam 3 kategori, yaitu: rendah (bila pada rentang 0-30), sedang (bila pada rentang 31-70), dan 
tinggi (bila pada rentang 71-100). Kedua metode yang disebutkan di atas, diilustrasikan seperti Gambar 2.

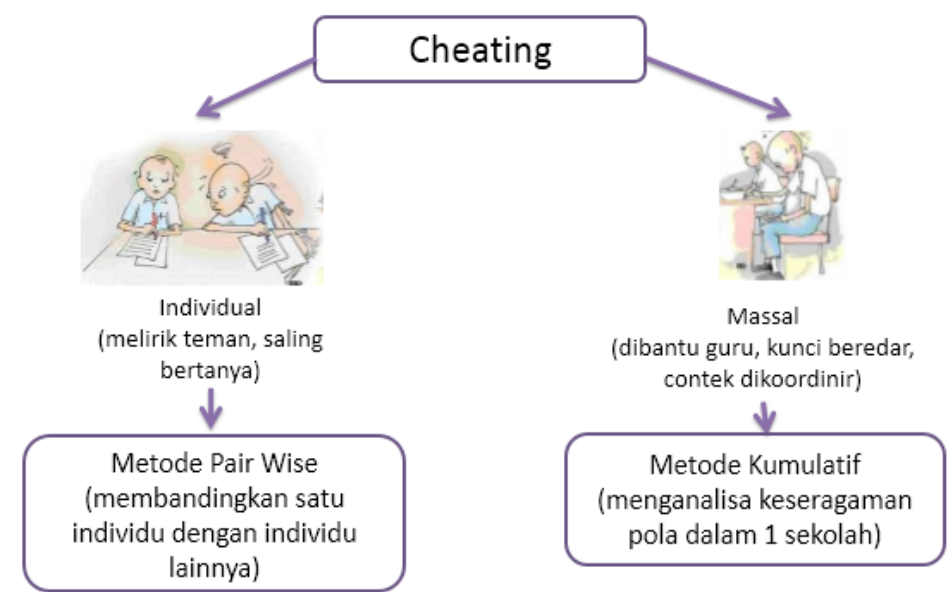

Gambar 2. Metode Deteksi Cheating

Populasi penelitian ini adalah seluruh Madrasah Aliyah dan SMA Islam di Indonesia berjumlah 6.608 MA/SMA Islam yang tersebar di 34 provinsi di Indonesia, yaitu DKI Jakarta, Banten, Jawa Barat, Jawa Tengah, DI Yogyakarta, Jawa Timur, Nangroe Aceh Darussalam (NAD), Sumatera Utara, Sumatera Barat, Riau, Jambi, Sumatera Selatan, Bangka Belitung, Bengkulu, Lampung, Kalimantan Barat, Kalimantan Tengah, Kalimantan Selatan, Kalimantan Timur, Sulawesi Utara, Gorontalo, Sulawesi Tengah, Sulawesi Selatan, Sulawesi Barat, Sulawesi Tenggara, Maluku, Maluku Utara, Bali, Nusa Tenggara Barat (NTB), Nusa Tenggara Timur (NTT), Papua, dan Irian Jaya Barat.

Sampel MA dan SMA Islam dipilih berdasarkan teknik purposive sampling. Untuk mengakomodasi teknik purposive sampling, dipilihlah satu provinsi yang memiliki MA dan SMA Islam terbanyak. Provinsi yang terpilih menjadi provinsi sampel adalah Jawa Timur dengan jumlah MA dan SMA Islam sebanyak 1.117. Keseluruhan MA dan SMA Islam itu tersebar di 38 kabupaten/kota. Selain jumlah MA dan SMA Islam di Jawa Timur terbanyak di Indonesia, dinamika permasalahan UN MA dan SMA Islam di Jawa Timur juga paling kompleks. Oleh karena itu, sangat relevan bila Jawa Timur dipilih menjadi sampel penelitian. 
Analisis data dilakukan dengan langkah sebagai berikut: pengodean, pencatatan dan penabelan, serta perhitungan statistik. Pengodean dan penabelan dilakukan terhadap data hasil Ujian Nasional yang dilaporkan dalam file yang sudah di CD-kan. Di dalamnya memuat statistik, daya serap dan daftar urutan nilai setiap sekolah, kabupaten, provinsi dan nasional. Pengkodean, pencatatan dan penabelan dilakukan oleh tiga orang terpisah: dua orang tim peneliti dengan validasi seorang ketua tim. Analisis statistik dilakukan untuk mencari: (1) Rerata capaian nilai UN dengan IIUN MA/SMA Islam di Provinsi Jawa Timur, (2) Rerata capaian nilai UN dengan IIUN SMA non-Islam di Provinsi Jawa Timur, dan (3) Perbandingan rerata capaian nilai IIUN MA/SMA Islam dengan SMA non-Islam di Provinsi Jawa Timur.

\section{B. Pembahasan}

Seperti telah diuraikan pada bagian sebelumnya, penelitian ini ingin mengungkap perilaku cheating yang dilakukan oleh siswa MA dan SMA Islam. Sebagai pijakan digunakan data hasil UN dan IIUN masing-masing MA dan SMA Islam tahun 2015. IIUN merupakan gambaran tingkat kejujuran dalam menjawab soal-soal ujian nasional. Semakin tinggi indeks integritas suatu madrasah atau sekolah, kabupaten/kota, maupun suatu wilayah menunjukkan tingkat kejujuran yang tinggi dalam pelaksanaan ujian nasional di madrasah/sekolah di wilayah tersebut. Kebalikan dari indeks integritas adalah indeks kecurangan. Semakin tinggi indeks integritas suatu sekolah atau wilayah, semakin rendah tingkat kecurangan (dalam bentuk cheating) sekolah atau wilayah tersebut.

Analisis hasil IIUN MA dan SMA Islam pada UN 2015 di Jawa Timur menunjukkan bahwa dari 38 kabupaten/kota yang ada, 28 di antaranya memiliki nilai IIUN di atas 50 . Sedangkan 10 lainnya memperoleh IIUN di bawah 50. Kesepuluh kabupaten/ kota yang memiliki nilai IIUN di bawah 50 jika diurutkan dari yang terkecil adalah Kabupaten Pamekasan $(27,58)$; Kabupaten Sumenep (29,99); Kabupaten Lumajang $(37,88)$; Kabupaten Probolinggo (40,93); Kabupaten Situbondo (40,95); Kota Probolinggo (44,68); Kabupaten Bondowo-so $(46,25)$; 
Kabupaten Jember (48,22); Kabupaten Banyuwangi (48,58); dan Kabupaten Bojonegoro $(49,40)$. Sementara itu, ada 8 kabupaten/ kota lainnya di provinsi ini yang memperoleh nilai IIUN di atas 70 dengan capaian tertinggi sebesar 79,21 dicapai oleh Kota Malang. Ketujuh kabu-paten/kota lain yang memperoleh IIUN di atas 70 jika diurutkan dari capaian terbesar antara lain Kota Batu $(76,77)$; Kabupaten Ngawi (76,62); Kota Blitar (74,70); Kabupaten Malang (72,15); Kabupaten Kediri (72,04); Kabupaten Nganjuk $(71,20)$; dan Kabupaten Pacitan (70,83).

Data di atas memperlihatkan bahwa umumnya MA/SMA Islam yang memiliki IIUN rendah tersebar di wilayah "tapal kuda" dan pinggiran. Di wilayah ini, jumlah MA/SMA Islam luar biasa banyak dan sebagian besar dikelola oleh yayasan keluarga yang kecil dan kurang kuat. Sebagian lagi dikelola pondok pesantren. Sudah dapat dipastikan bahwa MA/SMA Islam yang dikelola oleh yayasan kecil, memiliki dana terbatas bahkan cenderung kurang, sarana dan prasarana yang minim, input siswa yang kurang bagus, dan banyak guru yang miss-match. Di sisi lain, MA/SMA Islam yang dikelola oleh pondok pesantren, kualitas pendidikan umumnya seringkali juga kalah jika dibandingkan dengan sekolah umum lainya.

Berbagai keterbatasan yang ada pada MA/SMA Islam pada satu sisi, dan ketatnya standar kelulusan dan tingkat kesulitan soal UN pada sisi yang lain, maka munculah dampak negatif. Praktik kecurangan, manipulasi dan ketidakjujuran akhirnya menjadi suatu hal yang lumrah dalam pelaksanaan UN di MA/SMA Islam. Hal itu dilakukan oleh guru maupun siswa dengan modus yang sangat beragam. Menurut hemat penulis, itu semua terjadi sebagai bentuk empati sosial (social empahatic) dan rasa khawatir terhadap siswanya dalam upaya untuk mempertahankan "nama baik" madrasah.

Ada kata-kata yang dijadikan sebagai alasan pembenar di tengah-tengah para guru madrasah dalam melakukan praktek tidak jujur berupa memberikan contekan jawaban kepada muridnya yang sedang menjalani UN, yaitu "menolong demi kebaikan tidak apa-apa." Hal itu tentunya kontradiksi dengan apa yang sering didengungkan oleh para guru madrasah ketika meminta 
agar para siswa mereka benar-benar tidak mencontek hasil jawaban temannya. Ternyata dibalik itu, terjadi ketidakjujuran yang dilakukan guru itu sendiri untuk kepentingan kelulusan siswanya. Hal ini sama dengan memungkasi aktifitas pendidikan dengan ketidakbaikan, yaitu memberikan pemandangan perilaku tidak jujur kepada para siswa. Maka ketika siswa melihat gurunya dengan mudah berlaku tidak jujur, para siswa akan muncul sifat menirunya.

Secara jujur mereka memang juga mengakui bahwa pelaksanaan UN telah memotivasi siswa, guru maupun MA/ SMA Islam untuk meningkatkan proses pembelajaran (Supriyadi, 2000). Namun, hal itu tidak seimbang dengan beban sosial yang mereka tanggung. Siswa akan malu kalau nilainya jelek. Guru juga merasa malu kalau muridnya banyak yang nilainya jelek. Secara institusional, lembaga juga akan malu dan prestisnya akan turun bila muridnya (banyak yang) nilainya jelek. Implikasinya, MA/ SMA Islam akan semakin sulit mendapatkan siswa pada tahun ajaran berikutnya karena dianggap sebagai lembaga yang tidak berkualitas. Itu artinya, MA/SMA Islam akan tidak memiliki masa depan alias mati. Terutama untuk MA/SMA Islam swasta karena "nafas kehidupannya" sangat bergantung pada sumbangan pendidikan dari siswa. Itulah akar masalah-nya mengapa praktik dan perilaku cheating masal berjalan di MA/SMA Islam yang dikelola yayasan kecil. Yang berdampak nilai IIUN di MA/SMA Islam rendah.

Fakta ini menunjukkan bahwa faktor tekanan sebagaimana disinyalir dalam teori "Fraud Triangle," menjadi sebuah keniscayaan (Albrecht, 2012). Dalam pisau analisis teori ini, tekanan yang muncul untuk mendapatkan nilai UN yang baik guna memperjuangkan lembaganya merupakan faktor dominan. Sebuah nilai UN mempunyai dampak yang sangat kuat untuk mereka. Rasa gengsi kepada lembaga lain ketika mengetahui nilai UN mereka tidak memuaskan akan muncul. Dikarenakan sebuah nilai dianggap sebagai cerminan dari suatu keberhasilan lembaga, sehingga tak jarang nilai UN menjadi target keutamaan. Hal ini didukung dengan adanya fenomena bahwa di dalam beberapa kondisi, terkadang ada pernyataan dari pengelola MA dan SMA 
Islam yang tampak kurang percaya diri bahwa "Lembaga kami tidak akan bisa mendapatkan nilai UN yang kami inginkan tanpa berbuat kecurangan." Hal itu menunjukkan bahwa rasa malu yang muncul dalam diri seseorang guru dan pengelola MA dan SMA Islam ketika mendapatkan nilai UN yang kurang memuaskan serta beberapa alasan yang muncul untuk mendapatkan sebuah nilai UN, terkadang menutupi hati sanubari mereka. Sehingga membuat beberapa orang tidak perduli dan bersikap acuh tak acuh dengan cara yang mereka tempuh. Asalkan target mendapatkan nilai UN sesuai yang mereka harapkan.

Selanjutnya, bila sedikit menengok sekolah non-Islam (dalam penelitian ini SMA Kristen/Katolik), sekolah-sekolah tersebut menunjukkan hal yang lebih baik. Artinya, capaian nilai IIUN mereka lebih tinggi dibandingkan dengan MA/SMA Islam. Dari 20 kabupaten/kota yang memiliki SMA Kristen/ Katolik, hanya 1 (satu) kabupaten memperoleh nilai IIUN di bawah 50, yaitu Kabupaten Bojonegoro (sebesar 36,87). Capaian nilai IIUN tertinggi berada di Kabupaten Blitar, sebesar 79,95. Sementara itu, masih ada 9 kabupaten/kota memperoleh nilai IIUN di atas 70. Kesembilan kabupaten/kota tersebut jika diurutkan berdasarkan nilai tertinggi antara lain Kota Malang $(79,19)$; Kota Madiun $(75,77)$; Kota Surabaya $(75,69)$; Kota Batu (74,80); Kota Pasuruan (73,34); Kota Probolinggo (72,25); Kota Kediri $(71,75)$; Kabupaten Malang $(70,85)$; dan Kabupaten Sidoarjo $(70,08)$.

Bila dicermati, data capaian nilai IIUN untuk jenjang MA/SMA Islam maupun SMA Kristen/Katolik pada masingmasing kabupaten/kota menunjukkan hal yang berbeda di setiap wilayah. Setiap kabupaten/kota memiliki karakteristik tersendiri. Hasil analisis rerata nilai IIUN dari 20 kabupaten/ kota menunjukkan bahwa dalam 11 kabupaten/kota, rerata IIUN SMA Kristen/Katolik lebih tinggi dibandingkan dengan MA/ SMA Islam. Sedangkan dalam 9 kabupaten/kota lainnya, rerata IIUN MA/SMA Islam lebih tinggi dibandingkan dengan SMA Kristen/ Katolik.

Kabupaten Sidoarjo, Kota Probolinggo, Kota Kediri, Kabupaten Banyuwangi, Kabupaten Jember, Kabupaten 
Lumajang, Kabupaten Pasuruan, Kabupaten Blitar, Kota Kediri, Kota Surabaya, dan Kota Madiun adalah 11 kabupaten/kota dengan indeks IIUN yang diperoleh SMA Kristen/Katolik lebih tinggi dibandingkan dengan MA/SMA Islam. Selisih terbesar terjadi pada Kota Probolinggo, yaitu sebesar 27,57. Di kota ini rerata nilai IIUN MA/SMA Islam adalah 44,68 sedangkan rerata nilai IIUN SMA Kristen/Katolik mencapai 72,25.

Kota Malang, Kota Mojokerto, Kota Blitar, Kota Batu, Kabupaten Jombang, Kabupaten Bojonegoro, Kabupaten Nganjuk, Kabupaten Tulungagung, dan Kabupaten Trenggalek merupakan 9 kabupaten/ kota di Jawa Timur dengan perolehan rerata IIUN lebih unggul pada jenjang MA/SMA Islam dibandingkan SMA Kristen/Katolik. Selisih terbesar keunggulan IIUN MA/SMA Islam adalah sebesar 12,55 di Kota Mojokerto. Capaian rerata IIUN MA/SMA Islam di kota ini adalah 68,85 sedangkan rerata IIUN SMA Kristen/Katolik adalah 55,03. Untuk 10 kabupaten/ kota lainnya yang memiliki jenjang pendidikan MA/ SMA Islam dan SMA Kristen/Katolik selisih terbesar keunggulan IIUN SMA Kristen/Katolik adalah sebesar 12,55 di Kota Madiun. Di kota ini rerata nilai IIUN MA/SMA Islam adalah 63,22 sedangkan rerata nilai IIUN SMA Kristen/Katolik mencapai 75,77. Untuk lebih jelasnya perbandingan rerata nilai IIUN MA/SMA Islam dengan SMA Kristen/Katolik pada masing-masing kabupaten/kota di Jawa Timur disajikan pada Gambar 3. 


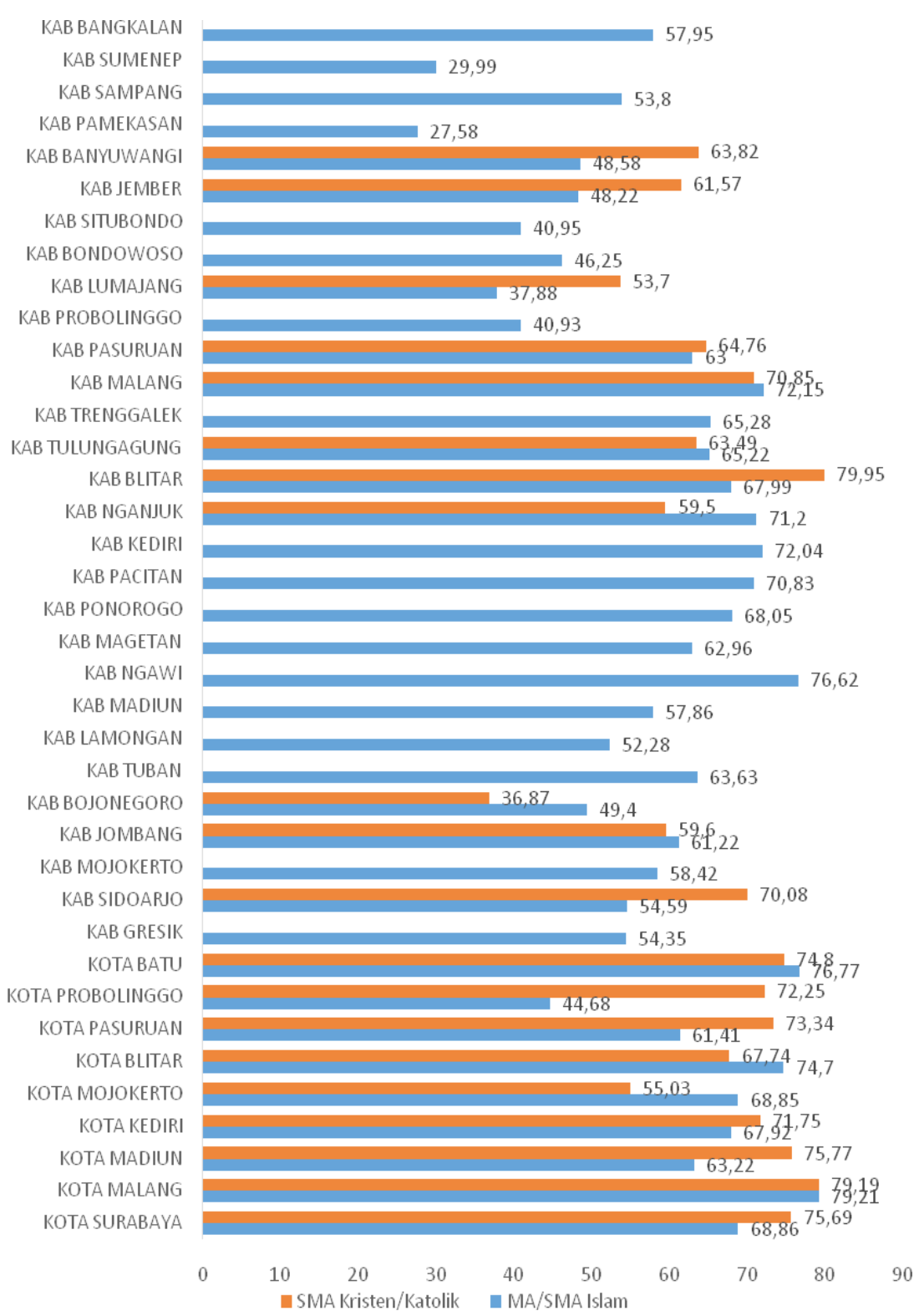

Gambar 3. Perbandingan Rerata Nilai IIUN MA/SMA Islam dengan SMA Kristen/Katolik di Provinsi Jawa Timur

Data di atas, bila disandingkan dengan data hasil UN akan didapatkan potret yang sedikit berbeda. Dari seluruh siswa MA/SMA Islam di provinsi ini, hanya 5,26\% yang memenuhi 
kriteria kelulusan UN (di atas 55) dengan indeks IIUN tinggi lebih dari 70. Artinya, persentase siswa yang lulus dengan sedikit kemungkinan melakukan kecurangan sangat rendah. Sebaliknya, sebanyak $73,86 \%$ dari seluruh siswa MA/SMA Islam di Jawa Timur memperoleh nilai UN yang memenuhi standar kelulusan minimal (SKL) dengan integritas rendah $(\leq 70)$. Artinya, lebih dari $70 \%$ siswa tersebut terindikasi melakukan kecurangan dalam pelaksanaan UN 2015.

Sementara itu, untuk SMA Kristen/Katolik di Provinsi Jawa Timur berbanding terbalik. Sebanyak $40 \%$ siswa mereka memenuhi kriteria kelulusan UN (di atas 60) dengan indeks IIUN tinggi lebih dari 70 . Hanya sebanyak $45 \%$ dari seluruh siswa mereka memperoleh nilai UN yang memenuhi standar kelulusan minimal (SKL) dengan integritas rendah $(\leq 70)$. Tentu ini ada sesuatu yang perlu dicari penyebabnya. Mengapa bisa demikian?

Tesis yang bisa dimunculkan adalah aspek input siswa, sarana dan prasarana penunjang KBM, serta guru yang dimiliki SMA Kristen/Katolik lebih baik. Jumlah SMA Kristen/Katolik di Jawa Timur yang sedikit juga turut menjadi penentu. Dengan jumlah yang sedikit dan mayoritas di ada di perkotaan, tentunya mempunyai keunggulan tersendiri dan berimbas pada kualitas input siswanya. Siswa yang masuk berasal dari keluarga yang secara ekonomi lebih mapan dibandingkan yang masuk MA dan SMA Islam. Mereka juga berasal dari keluarga yang fanatik, dan secara ideologi keagamaan tidak akan mau memasukkan anaknya selain ke SMA Kristen/Katolik. Walaupun sebenarnya, anak mereka bisa saja diterima di sekolah negeri. Faktor ini tentu berdampak pada sarana prasarana dan kualitas guru yang dimiliki SMA Kristen/Katolik.

Hasil di atas memperlihatkan kepada kita bahwa tingkat kejujuran pelaksanaan UN di MA/SMA Islam rendah dan kalah dibandingkan dengan SMA Kristen/Katolik. Artinya, praktik dan tindakan cheating membudaya di kalangan MA/SMA Islam. Sekali lagi, akar masalahnya disebabkan adanya berbagai keterbatasan yang dimiliki oleh MA/SMA Islam untuk berlangsungnya proses pembelajaran berkualitas. Dalam kondisi seperti ini, guru, siswa dan pihak-pihak terkait akhirnya "berkompromi" dan "bersatu" 
untuk melakukan tindakan yang sangat bertentangan dengan akhlakul karimah. Suatu tindakan yang tidak dibenar-kan secara hukum (Supaat, 2013: 347).

Yang penting mendapat predikat lulus dan sebisa mungkin dengan nilai tinggi. "Jalan pintas" dan praktik-praktik tidak terpuji dianggap "sah dan pantas" demi sebuah predikat "lulus." Yang lebih menarik, upaya-upaya manipulatif dan kompromistik tersebut semakin kreatif dari tahun ke tahun, yang sesungguhnya adalah sebuah proses menuju ke arah demoralisasi anak bangsa. Ini tentu sangat bertentangan dengan jati diri MA dan SMA Islam sebagai lembaga berciri khas Islam.

Gambar 4 berikut menunjukkan persentase siswa yang memperoleh nilai UN di bawah SKL $(\leq 55)$. Sedikitnya terdapat $5,26 \%$ dari seluruh siswa MA/SMA Islam memperoleh nilai UN di bawah SKL dengan IIUN rendah $(\leq 70)$. Meskipun demikian, masih ada sekitar $15,79 \%$ siswa MA/SMA Islam memperoleh nilai UN di bawah SKL dengan integritas tinggi (di atas 70). Artinya, hampir 16\% siswa tersebut memperoleh nilai UN berdasarkan kemam-puannya sendiri atau tidak terindikasi melakukan kecurangan dalam melaksanakan UN.

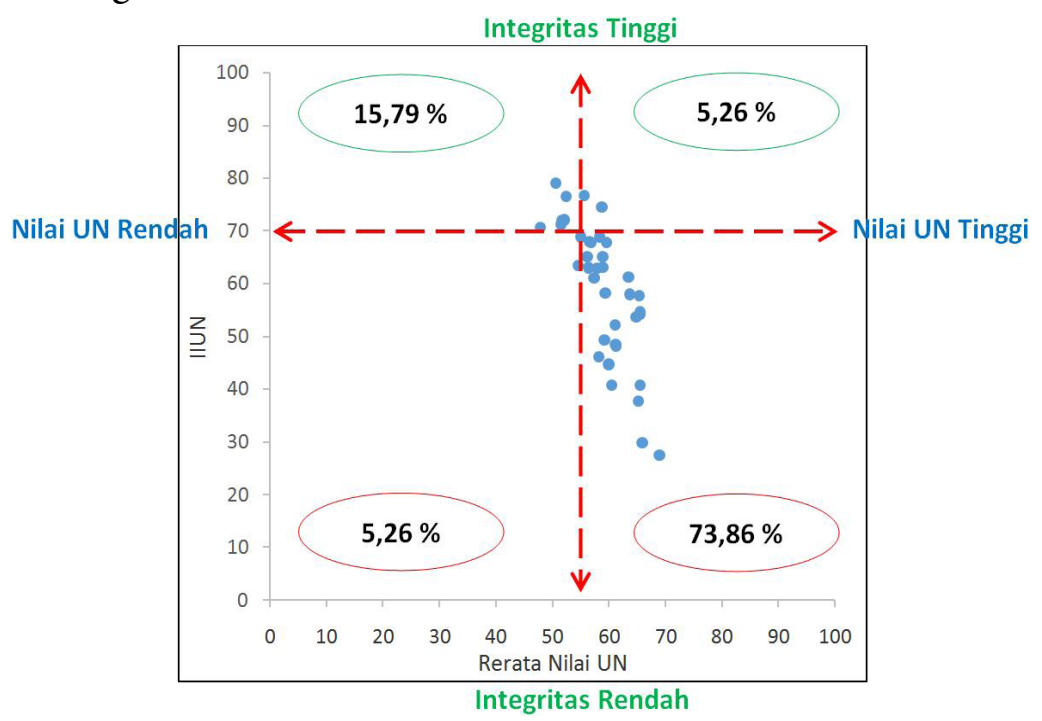

Gambar 4. Grafik Perbandingan Rerata Nilai UN dengan IIUN MA/ SMA Islam di Provinsi Jawa Timur 
Di sisi lain, untuk SMA Kristen/ Katolik hasil analisis IIUN menunjukkan bahwa sekitar $40 \%$ dari seluruh siswa yang ada memperoleh nilai UN di atas SKL dengan IIUN tinggi ( 70). Artinya, 40\% dari keseluruhan siswa yang ikut UN tidak melakukan kecurangan dan berhasil memperoleh nilai yang memenuhi SKL. Persentase ini nyatanya jauh lebih tinggi dibandingkan persentase siswa MA/SMA Islam yang hanya 5,26\%.

Selebihnya, 45\% dari seluruh siswa SMA Kristen/Katolik di Jawa Timur mendapatkan nilai UN di atas SKL dengan integritas rendah $(\leq 70)$. Ini menunjukkan masih ada $45 \%$ dari keseluruhan siswa SMA Kristen/Katolik di provinsi ini berhasil mencapai standar kelulusan nilai UN dengan indikasi melakukan kecurangan pada pelaksanaannya. Uraian di atas disajikan pada Gambar 5 .

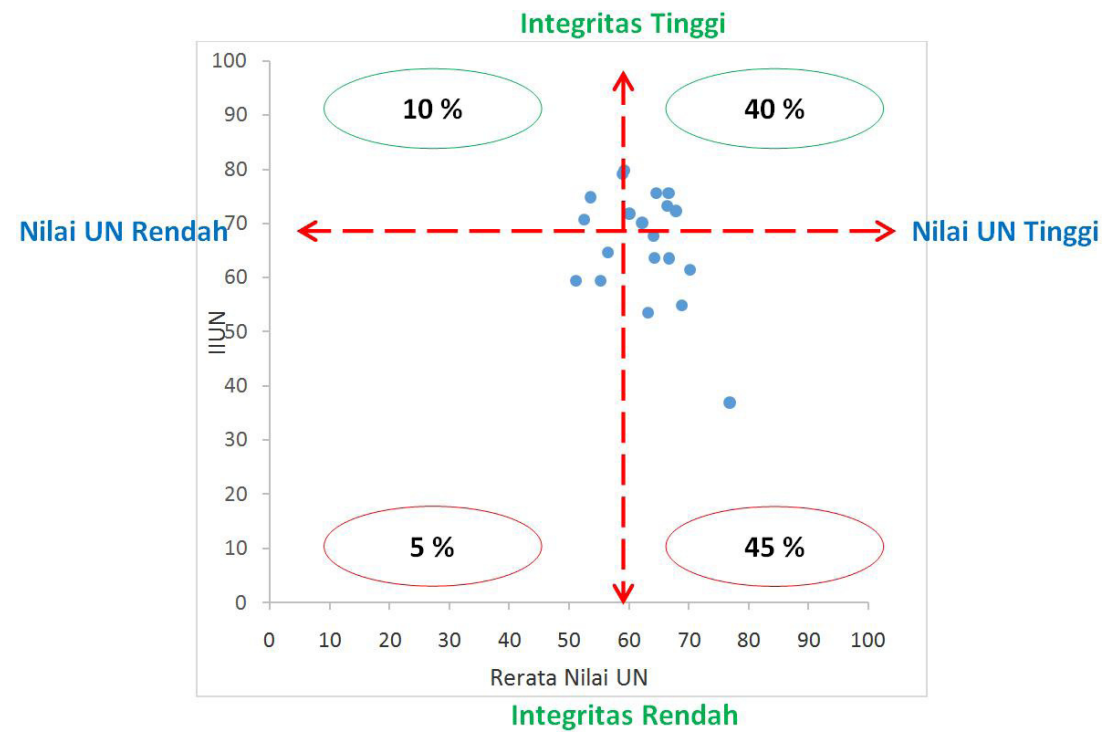

Gambar 5. Grafik Perbandingan Rerata Nilai UN dengan IIUN SMA Kristen/Katolik di Provinsi Jawa Timur

Perbedaan yang mencolok antara indeks IIUN siswa dari MA/SMA Islam dengan SMA Kristen/Katolik, dipengaruhi pula oleh aspek pembelajaran. Mata pelajaran dan jam belajar yang harus diikuti oleh siswa MA/SMA Islam luar biasa banyak dan panjang dibanding dengan siswa SMA Kristen/Katolik. Padahal secara faktual mayoritas siswa MA/SMA Islam, umumnya berasal 
dari kalangan menengah ke bawah yang secara ekonomi akan mengalami beberapa kendala untuk mengikuti pembelajaran tambahan. Beda dengan siswa yang berasal SMA Kristen/ Katolik. Mereka umumnya berasal dari kalangan menengah ke atas. Dari aspek finansial dan kesehatan lebih baik.

Kegiatan belajar yang melampaui kapasitas dan kemampuan siswa siswa MA/SMA Islam telah berpengaruh negatif bagi kesehatan dan mental siswa. Tidak jarang mereka menjadi sakit dan terganggu pikirannya ketika menjelang pelaksanan UN. Di sisi lain, mereka juga mengalami ketakutan bila tidak lulus di UN yang mereka ikuti. Munculah rasa percaya diri yang rendah di antara mereka.

Ketika rasa percaya diri siswa MA dan SMA Islam rendah, "jalan pintas" dan praktik-praktik tidak terpuji akhirnya terpaksa dilakukan (Hartanto, 2012:24). Siswa yang memiliki kepercayaan diri rendah juga akan menunjukkan sikap pesimis terhadap kemampuan dirinya sehingga melakukan tindakan cheating sebagai cara menghindari kegagalan (Solagrasia, 2014:177). Hal itu dianggap sebagai sesuatu yang sah dan lumrah. Mereka meyakini apa yang mereka lakukan itu benar. Bukan hanya satu, dua atau tiga orang yang pernah melakukan, namun tidak ada tindakan tegas. Jadi mereka merasa ketika tindakan cheating yang dilakukan tidak akan bermasalah. Dalam konteks ini rasionalisasi yang bermunculan dari dalam diri mereka, akan memunculkan anggapan bahwa semua hal yang mereka lakukan akan terlihat wajar dan dapat diterima akal. Mereka akan mencari celah dan alasan untuk menutupi rasa bersalah mereka dan mencari pembenaran atas tindakan yang mereka lakukan.

\section{Simpulan}

Berdasarkan paparan sebelumnya, maka dapat dirumuskan simpulan bahwa perilaku cheating yang dilakukan oleh siswa MA dan SMA Islam di Jawa Timur pada UN 2015 sangat tinggi. Konstribusi terbesar dilakukan pada MA dan SMA Islam di wilayah pinggiran dan daerah 'tapal kuda.' Di wilayah ini, jumlah MA/SMA Islam luar biasa banyak dan sebagian besar dikelola oleh yayasan keluarga yang kecil dan kurang kuat, dan sebagian 
lagi dikelola pondok pesantren. Keterbatasan yang mereka miliki (seperti sarana prasarana yang minim, input siswa yang kurang bagus, dan banyak guru yang miss-match) berdampak pada rendahnya kualitas proses pembelajaran.

Rendahnya kualitas proses pembelajaran dan tingginya tingkat kesulitan soal UN, mendorong mereka untuk melakukan praktik cheating masif. Hal itu dilakukan oleh guru maupun siswa, dengan modus yang sangat beragam, sebagai bentuk empati sosial (social empahatic) dan rasa khawatir terhadap siswanya dalam upaya untuk mempertahankan "martabat" dan "nama baik" lembaga. 


\section{DAFTAR PUSTAKA}

Albrecht, W. Steve. 2012. Fraud Examination. Ohio: Mason SouthWestern Cengage Learning.

Becker, J. C., Paula L, and Morrison, J. 2006. Using the Business

Fraud Triangle to Predict Academic Dishonesty Among Business Students. Academy of Educational Leadership Journal, Vol. 10, No 1:37-53.

Departemen Pendidikan dan Kebudayaan. 2008. Kamus Besar Bahasa Indonesia. Jakarta: Balai Pustaka.

Eisenberg, Jacob. 2004. To Cheat or Not To Cheat: Effects Of Moral Perspective And Situational Variables On Students' Attitudes. Journal of Moral Education, Vol. 33, No 2: 163-178.

Friyatmi. 2011. Faktor-faktor Penentu Perilaku Mencontek di Kalangan Mahasiswa Fakultas Ekonomi UNP. Jurnal Tingkap, Vol. 7, No 2: 173-188.

Hartanto, Dody. 2012. Menyontek: Mengungkap Akar Masalah dan Solusinya. Jakarta: Indeks.

Kementerian Agama RI. 2015. Madrasah Indonesia: Madrasah Prestasiku, Madrasah Pilihanku. Jakarta: Direktorat Pendidikan Madrasah Direktorat Jenderal Pendidikan Islam Kementerian Agama RI.

Kemendikbud. 2014. Laporan Hasil Ujian Nasional Tahun 2014. Jakarta: Pusat Penilaian Pendidikan Balitbang Kemendikbud.

Kemendikbud. 2015. Laporan Hasil Ujian Nasional Tahun 2015. Jakarta: Pusat Penilaian Pendidikan Balitbang Kemendikbud.

Kemendikbud. 2015. Pemanfaatan Hasil Ujian Nasional untuk Seleksi Masuk ke Jenjang Pendidikan Selanjutnya. Jakarta:

Pusat Penilaian Pendidikan Balitbang Kemendikbud.

Kemendikbud. 2015. Penjelasan tentang Indeks Cheating. Jakarta:

Pusat Penilaian Pendidikan Balitbang Kemendikbud. 
Manopo, Yance \& Mardapi, Djemari. 2014. Analisis Metode Cheating pada Tes Berskala Besar. Jurnal Penelitian dan Evaluasi Pendidikan, Vol.18, No.1:115-128.

Maududi, Abul A. 1986, Dasar-Dasar Iman. Bandung: Pustaka.

Nonis, S., \& Swift, C. O. 2001. An Examination of The Relationship between Academic Dishonesty and Workplace Dishonesty: A Multi-campus Investigation. Journal of Education for business, Vol. 77, No. 2: 69-77.

Ridlwan, Mujib. 2015. Studi korupsi dalam kulturasi manajemen madrasah di Tuban. AL HIKMAH Jurnal Studi Keislaman, Vol. 5, No. 1:102-113.

Sabiq, Sayyid. (tt). Inilah Islam. Semarang: CV Toha Putra.

Solagrasia, Kartika. 2014. Perilaku Menyontek pada Siswa Ditinjau dari Kepercayaan Diri dan Strategi Coping. Jurnal Talenta Psikologi, Vol. 3, No. 2: 160-179.

Steiner, Mark A. 1932. Cheating in School. Journal The School Review.Vol. 40, No. 7: 535 - 546.

Strom, Paris S. \& Strom, Robert D. 2007. Cheating Middle School and High School. The Education Forum, Vol. 71, No. 2: 104-116.

Supaat. 2013. Madrasah dan Ujian Nasional. Nadwa: Jurnal Pendidikan Islam, Vol. 7, No. 2: 335-362

Supriyadi, Dedi. 2000. Mengangkat Citra Guru dan Martabat Guru. Yogyakarta: Adicita Karya Nusantara.

Undang-undang RI Nomor 20 Tahun 2003 tentang Sistem Pendidikan Nasional.

Warsiyah. 2013. Perilaku Menyontek Mahasiswa Muslim (Pengaruh Tingkat Keimanan, Prokrastinasi Akademik dan Sikap terhadap Menyontek pada Perilaku Menyontek Mahasiswa Fakultas Tarbiyah IAIN Walisongo). Tesis tidak diterbitkan. Semarang: PPs IAIN Walisongo Semarang. 
Kusaeri 